\title{
ANALISIS DATA KUALITATIF DALAM PENELITIAN PARIWISATA
}

\author{
Oleh: \\ ILHAM JUNAID \\ Politeknik Pariwisata Makassar, Jl. Gunung Rinjani, Metro Tanjung Bunga, Makassar \\ Email: illank77@yahoo.co.id
}

\section{Abstrak}

Tujuan karya tulis ini adalah untuk menguraikan secara komprehensif ciri, defenisi dan tahap-tahap analisis data kualitatif bidang pariwisata. Tulisan ini didasarkan pada review literatur yang berkaitan dengan metodologi penelitian kualitatif. Peneliti kualitatif pada umumnya diperhadapkan pada banyaknya data atau informasi yang bersifat kata-kata atau kalimat baik data dari dokumen, wawancara, observasi maupun diskusi kelompok terfokus. Kenyataannya, tidak sedikit peneliti kualitatif tidak memahami langkah atau proses mengembangkan pengetahuan dari data kualitatif khususnya karena banyaknya data yang harus dianalisis. Akibatnya, hasil penelitian cenderung bersifat deskriptif tanpa memberikan kontribusi terhadap pengembangan ilmu pengetahuan. Analisis tematik (thematic analysis) adalah jenis analisis yang paling banyak dimanfaatkan dalam penelitian kualitatif yang pelaksanaannya melalui langkah reduksi data, pengorganisasian dan interpretasi. Langkah coding merupakan kunci keberhasilan menganalisis data kualitatif. Karenanya, contoh analisis data penelitian pariwisata juga diberikan untuk memberikan gambaran praktis dari analisis data kualitatif bidang pariwisata.

Kata kunci: analisis tematik, analisis data kualitatif, coding, penelitian pariwisata

\begin{abstract}
This paper aims at exploring the definition, characteristics and stages of qualitative data analysis in tourism research. The paper is based on review of literature on qualitative research methodology. Qualitative researchers may deal with different and rich data from qualitative methods. However, many qualitative researchers do not understand how to produce knowledge from qualitative data. For this reason, the result of a qualitative research tends to be descriptive without contributing to the advancement of knowledge. Thematic analysis is considered as a dominant form of analysis in qualitative research. Its stages consist of data reduction, organization and interpretation. Coding is the key for successful qualitative data analysis. Hence, examples of qualitative data analysis in tourism research are provided to give practical stages of how to analyze qualitative data.
\end{abstract}

Keywords: thematic analysis, qualitative data analysis, coding, tourism research 


\section{PENDAHULUAN}

Pada bulan November tahun 2015, penulis pernah ditanya oleh seorang mahasiswa program studi kepariwisataan perihal bagaimana ia (mahasiswa tersebut) seharusnya memulai melakukan analisis data pada penelitian kualitatif. Mahasiswa tersebut menyampaikan bahwa ia telah melakukan wawancara kepada lebih dari 10 (sepuluh) orang dan melakukan pencatatan melalui observasi ketika berada di lokasi penelitian. Namun, mahasiswa tersebut bingung dengan banyaknya data yang diperoleh di lapangan. Penulis juga pernah mengalami hal yang sama dimana penelitian yang dilakukan telah melibatkan lebih dari 20 (dua puluh) informan melalui wawancara dan lebih dari 20 (dua puluh) orang (masyarakat) yang terlibat dalam diskusi kelompok terfokus (focus-group discussion).

Banyaknya ragam data atau informasi yang disampaikan oleh informan menjadikan mahasiswa tersebut dan penulis tersendiri berfikir bagaimana data-data tersebut seharusnya diolah dan dianalisis agar mampu menghasilkan penelitian yang memiliki nilai atau kontribusi terhadap pengetahuan. Menurut Long (2007), tantangan yang dihadapi oleh peneliti kualitatif adalah bagaimana menjadikan informasi yang disampaikan oleh informan menjadi bermakna yang selanjutnya mampu mengembangkan khasanah keilmuan sesuai bidang penelitiannya.

Penelitian kualitatif bidang pariwisata juga telah dimanfaatkan oleh banyak peneliti. Jika sebelumnya pendekatan kuantitatif banyak digunakan dalam menginvestigasi isu atau masalah yang berkaitan dengan pariwisata melalui pendekatan statistik, banyak peneliti justru telah beralih ke penelitian kualitatif dalam mengamati fenomena sosial yang terjadi di masyarakat. Goodson dan Phillimore (2004) berpendapat bahwa proses beralihnya peneliti dari metodologi kuantitatif ke kualitatif ini tidak terlepas dari kritik tentang bagaimana kontribusi penelitian kuantitatif dalam pengembangan pengetahuan di bidang ilmu-ilmu sosial.

Penelitian kuantitatif cenderung lebih terfokus pada isu-isu yang berkaitan dengan metodologis dan kuantifikasi. Sementara, proses bagaimana pengetahuan dapat dihasilkan dari fenomena sosial tersebut cenderung kurang diperhatikan. Mengingat fokus peneliti lebih mengarah pada bagaimana hasil dari suatu metode yang digunakan (melalui statistik), penelitian kuantitatif terbatas dalam memahami bagaimana eksplanasi dan pemahaman terhadap suatu fenomena yang terjadi (Goodson dan Phillimore, 2004). Mengingat penelitian di bidang pariwisata melibatkan manusia sebagai subjek sekaligus objek dalam menghasilkan pengetahuan (Junaid, 2015), eksplanasi fenomenasi sosial di bidang pariwisata kurang menjadi perhatian penelitian kuantitatif.

Sebaliknya, penelitian kualitatif tidak terlepas dari kritik. Data-data yang diperoleh melalui metode kualitatif tidak memiliki standar yang baku dalam hal perhitungan. Apa yang 
disampaikan oleh informan dan dilihat oleh peneliti tidak dapat dikuantifikasi sebagaimana layaknya standar statistik yang digunakan dalam penelitian kuantitatif (Alasuutari, 2010; Long, 2007). Menurut Long, pertanyaanpertanyaan seperti 'data apa yang telah saya peroleh; apa makna dari semua data yang diperoleh, dan apa yang ada dalam data tersebut dan bagaimana data-data itu mampu menarik dan bermanfaat untuk orang lain atau peneliti lain', terkadang muncul ketika penelitian kualitatif digunakan oleh peneliti. Dengan kata lain, penelitian kualitatif yang tidak memanfaatkan pendekatan statistik menjadik kritik bagi banyak peneliti.

Uraian di atas mengisyaratkan bahwa perlu ada eksplanasi yang jelas, konkrit dan aplikatif dalam menganalisis data-data penelitian kualitatif. Penelitian pariwisata sering melibatkan interaksi antara informan dan peneliti itu sendiri. Meneliti pendapat masyarakat tentang pariwisata (ataupun dampak-dampak pariwisata terhadap kehidupan masyarakat) di suatu destinasi misalnya, menghendaki interaksi antara peneliti dan masyarakat suatu destinasi itu sendiri. Interaksi ini menuntut peran dan kerja keras dari peneliti agar apa yang disampaikan oleh informan dapat diinterpretasikan secara akurat, memerhatikan prinsip objektifitas dan netralitas.

Untuk mencapai tujuan tersebut, maka pemahaman peneliti mengenai langkah-langkah yang tepat dan akurat dalam menganalisis data dari informan (serta data kualitatif lainnya) sangat penting diperhatikan. Hal ini penting untuk meminimalisir kecenderungan peneliti yang bersifat subjektif dalam memahami data tanpa melakukan langkah-langkah prosedural dalam menganalisis data.

Pengembangan pengetahuan di bidang pariwisata dibangun oleh beberapa pendekatan baik yang menerapkan metodologi kualitatif maupun kuantitatif. Ketika penelitian kualitatif digunakan oleh peneliti, maka analisis yang tepat akan membantu peneliti dalam menghasilkan pengetahuan baru atau mengembangkan ide-ide (teori) yang telah ada sebelumnya. Tulisan ini merupakan kajian kritis tentang bagaimana langkah-langkah atau prosedur yang seharusnya diterapkan oleh peneliti dalam menganalisis data penelitian kualitatif di bidang pariwisata.

Menurut Moore (2006), penggunaan dan pemahaman statistik dan komputer dalam penelitian kuantitatif menimbulkan opini bahwa menganalisis data kuantitatif lebih sulit dibandingkan analisis data kualitatif. Moore menambahkan bahwa analisis data kualitatif justru merupakan proses yang berat dan membutuhkan konsentrasi dan kemampuan peneliti dalam berfikir dan berintuisi yang baik dalam melihat data. Karenanya, tulisan ini diharapkan memberikan gambaran dan acuan bagi peneliti dalam menganalisis data kualitatif khususnya penelitian di bidang pariwisata. 


\section{PEMBAHASAN}

\section{Sifat dan Defenisi Penelitian Kualitatif}

Bagi beberapa peneliti, penelitian kualitatif terkadang sulit didefinisikan. Argumentasi yang paling banyak digunakan adalah bahwa penelitian kualitatif adalah penelitian yang tidak memanfaatkan angka-angka, berlawanan dengan penelitian kuantitatif. Pendapat ini tidak dapat disalahkan mengingat datadata yang diperoleh dalam penelitian kualitatif lebih bersifat kata-kata atau informasi. Namun demikian, penelitian kualitatif dapat diidentifikasi dan dipahami dengan melihat cakupan atau feature yang terdapat pada penelitian kualitatif. Flick (2007) berpendapat bahwa penelitian kualitatif adalah penelitian yang diperuntukkan untuk memahami, menguraikan, dan bahkan menjelaskan fenomena sosial yang ada dengan cara-cara sebagai berikut:

- Dengan menganalisis pengalaman dari individu-individu atau kelompok (misalnya masyarakat). Pengalaman ini dapat berkaitan dengan sejarah hidup seseorang, pengetahuannya ataupun cerita yang berkaitan dengan hidupnya.

- Dengan menganalisis interaksi dan komunikasi setiap individu atau kelompok.

- Dengan menganalisis dokumendokumen (misalnya teks, gambar, film atau musik).

Penelitian kualitatif mencoba menguraikan realita ataupun fenomena yang ada di masyarakat dari sudut pandang informan atau orang yang berpartisipasi dalam penelitian tersebut (Baez, 2002; Flick, Kardorffdan Steinke, 2004; Maykut dan Morehouse, 1994). Realita atau fenomena tersebut dapat dipahami melalui pengumpulan data yang dilakukan melalui wawancara (termasuk wawancara mendalam), observasi (termasuk participant observation, diskusi kelompok terfokus dan analisis dokumen (Belsky, 2004; Snape dan Spencer, 2003).

Sesungguhnya, realitas sosial yang ada di masyarakat memiliki makna sehingga penelitian kualitatif bertujuan untuk memahami apa yang terjadi baik dilihat dari prosesnya maupun pola-pola makna yang terjadi di masyarakat. "The way in which people being studied understand and interpret their social reality is one of the central motifs of qualitative research" (Bryman, 1998:8). Cara peneliti memahami dan menginterpretasi realitas sosial masyarakat, komunitas atau orang merupakan tujuan utama dari penelitian kualitatif. Penelitian kualitatif senantiasa melihat realitas sosial dalam konteks apa yang terjadi dan mengapa sesuatu terjadi di masyarakat. Selanjutnya, penelitian kualitatif memberikan solusi, pendekatan ataupun strategi yang dapat ditempuh berdasarkan fenomena yang sedang dipelajari atau diteliti.

Denzin dan Lincoln (2003:3) memberikan defenisi penelitian kualitatif sebagai berikut:

"Qualitative research is a situated activity that locates the observer in the world. It consists of a set of 
interpretive, material practices that makes the world visible. These practices... turn into a series of representation including fieldnotes, interviews, conversations, photographs, recordings and memos to the self. At this level, qualitative research involves an interpretive naturalistic approach to the world. This means that qualitative researchers study things in their nautral settings, attempting to make sense of, or to interpret, phenomena in terms of the meanings people bring to them".

Menurut Denzin dan Lincoln, penelitian kualitatif menempatkan peneliti atau pengamat suatu fenomena sebagai bagian yang tak terpisahkan dari fenomena tersebut. Penelitian kualitatif terdiri dari perangkat atau rangkaian kegiatan yang bersifat interpretatif yang membuat apa yang ada di dunia ini menjadi nampak. Rangkaian kegiatan tersebut dapat terdiri dari catatan lapangan, wawancara, percakapan, fotografi, rekaman, dan catatan pribadi (memo). Mengingat penelitian kualitatif menerapkan pendekatan interpretasi data, maka peneliti kualitatif akan mengkaji suatu realita ataupun fenomena dalam konteks alami, memberikan makna atau menginterpretasi suatu data berdasarkan makna dari suatu studi.

\section{Penelitian Kualitatif Bidang Pariwisata \\ Dalam penelitian pariwisata,} penelitian kualitatif telah mendapat perhatian, bahkan menjadi perdebatan diantara dari para penulis dan peneliti bidang pariwisata (Phillimore dan Goodson, 2004). Fokus utama penelitian kualitatif bidang pariwisata adalah mengumpulkan informasi atau data yang berkaitan dengan aktifitas atau kegiatan, peristiwa atau kejadian, tingkah laku yang terjadi dalam konteks sosial serta mencari pemahaman tentang tindakan, masalah dan proses yang terjadi di masyarakat dalam konteks social khususnya yang berkaitan dengan pariwisata. Dalam hal ini, penelitian kualitatif sering dibedakan dengan penelitian kuantitatif yang menghasilkan data atau hasil penelitian berupa angkaangka, pengukuran dan hipotesis (Phillimore dan Goodson, 2004). Jadi, penelitian kualitatif dianggap sebagai sebuah strategi dalam memahami realitas sosial.

Penelitian kualitatif terkadang mendapat kritik dari para peneliti yang memegang prinsip positivisme (positivists). Hal ini didasarkan pada alasan bahwa penelitian kualitatif tidak dapat dikuantifikasi sebagaimana layaknya penelitian kuantitatif. Akibatnya, penelitian kualitatif terkadang dianggap lemah dalam hal objektifitas (objectivity) dan generalisasi (generalisability) (Decrop, 2004). Dalam hal ini, upaya untuk menjelaskan kriteria keilmiahan penelitian kualitatif telah menjadi kajian banyak peneliti.

Penelitian kualitatif juga memiliki empat kriteria yang menggambarkan kriteria keilmiahan sebagaimana layaknya penelitian kuantitatif (Bryman, Becker dan Sempik, 2008; Decrop, 2004; Decrop, 1999; Seale, 2004; Steinke, 2004). 
Kredibilitas (credibility) dalam penelitian kualitatif sering disamakan dengan validitas internal (internal validity) dalam penelitian kuantitatif. Kredibitilitas mengacu pada bagaimana temuan penelitian bernilai benar atau sungguh-sungguh. Transferabiliti (transferability) sering dikaitkan dengan validitas eksternal (external validity) yang diartikan sebagai sejauh mana hasil suatu penelitian dapat diterapkan dalam setting atau kelompok yang lain. Ketergantungan (dependability) yang disejajarkan dengan reliability diartikan sebagai apakah hasil suatu penelitian bersifat konsisten atau tidak.

Selanjutnya, confirmability yang disesuaikan dengan objectivity didefenisikan sebagai bagaimana kenetralan suatu hasil penelitian. Kajian pariwisata dapat mencakup studi tentang dimensi atau aspek yang berhubungan dengan manusia. Karenanya, penelitian kualitatif sangat tepat digunakan untuk memahami segala aspek yang berkaitan dengan manusia dan kaitannya dengan pariwisata atau kepariwisataan.

Sebagai contoh, pariwisata memiliki implikasi baik yang bersifat sosial, budaya, ekonomi (bahkan dapat berkaitan dengan politik) di masyarakat atau suatu destinasi wisata, sehingga untuk mengkaji aspek-aspek tersebut, penelitian kualitatif dapat menjadi metode, pendekatan bahkan strategi dalam memahami fenomena yang terjadi. Menurut Goodson dan Phillimore (2004), meskipun peneliti bidang pariwisata meneliti aspek penghitungan (kuantifikasi) mengenai aspek-aspek yang ada di lapangan, eksplorasi tentang makna dan pemahaman terhadap apa yang mereka amati dan teliti masih terbatas dalam menyelesaikan atau menangani isu-isu yang berkaitan dengan pengalaman yang melibatkan manusia.

\section{Tahap Analisis Data Kualitatif}

Analisis data penelitian kualitatif seharusnya dimulai pada awal penelitian. Ketika seseorang melakukan penelitian, maka di saat itu pula ia (peneliti) akan berhadapan dengan data-data baik data-data dari teks atau dokumen, melalui catatancatatan observasi ataupun melalui wawancara. Pada saat yang sama, peneliti akan membaca data-data tersebut (mungkin berkali-kali) yang selanjutnya akan memberikan makna terhadap data yang dibaca tersebut. Analisis data di awal penelitian akan memudahkan peneliti dalam menerapkan strategi yang akan digunakan dalam mengumpulkan datadata atau informasi baru selanjutnya. Mengingat peneliti akan melakukan pengumpulan data melalui wawancara dengan informan lain, maka analisis data yang dilakukan lebih awal akan menjadi panduan peneliti dalam menggali informasi dari informan.

Setelah mengumpulkan data melalui wawancara dan observasi, maka hal yang pertama dihadapi oleh seorang peneliti adalah berhadapan dengan data-data penelitian. Data-data tersebut membutuhkan pengorganisasian yang kemudian disebut sebagai analisis data. Altinay dan Paraskevas (2008: 167) mengemukakan "qualitative data analysis is the conceptual 
interpretation of the dataset as a whole, using specific analytic strategies to convert the raw data into a logical description and explanation of the phenomenon under study". Analisis data kualitatif adalah intepretasi konsep dari keseluruhan data yang ada dengan menggunakan strategi analitik yang bertujuan untuk mengubah atau menerjemahkan data mentah ke dalam bentuk uraian atau deskripsi dan eksplanasi dari fenomena yang sedang diteliti dan dipelajari.

Dalam penelitian kualitatif, analisis data merupakan proses yang berkelanjutan yang dilakukan oleh peneliti dengan fokus pada data-data yang telah dikumpulkan (Bryman, 2012; Dey, 1993; Ritchie, Spencer dan O'Connor, 2003; Sarantakos, 1993). Proses yang berlangsung secara terus menerus ini menuntut peneliti mengorganisasikan data-data yang telah diperoleh sehingga data-data tersebut menjadi jelas, dapat dipahami dan memberikan makna. Dalam implementasinya, analisis data kualitatif dilakukan melalui tiga tahap atau proses yakni reduksi data (data reduction), pengorganisasian (organisation), dan interpretasi data (interpretation) (Fielding dan Fielding, 2008; Sarantakos, 1993).

Reduksi data diartikan sebagai suatu proses mengidentifikasi data mentah (raw data) yang telah diperoleh dengan melakukan langkah summary, pengkodean (coding) dan kategorisasi (categorising). Pengorganisasian diartikan sebagai proses mengumpulkan atau menyatukan informasi data yang dihasilkan dari identifikasi awal (proses reduksi data). Hasil analisis dari langkah reduksi data dan pengorganisasian tersebut selanjutnya dilakukan interpretasi data. Interpretasi data ini sangat penting untuk menghasilkan kesimpulan berdasarkan pertanyaan penelitian. Pemahaman informasi, teori, dan keilmuan (pengetahuan) peneliti perihal isu atau topik yang sedang diteliti berperan penting dalam proses interpretasi data.

Mannan (2000) juga berpendapat bahwa proses analisis data kualitatif dilakukan dengan melakukan prinsip atau langkah yakni familiarisasi data (familiarisation with data), mengorganisir data (organising data), menyajikan data (displaying data), membuat atau menarik kesimpulan (drawing conclusions), melakukan verifikasi atau pengecekan (verification/checking) dan menghubungkan teori (linking theory).

Analisis data kualitatif memiliki jenis-jenis atau pendekatan tergantung pemilihan peneliti dalam menggunakan jenis analisis data yang tentunya disesuaikan dengan metodologi dan tujuan penelitian. Menurut Liamputtong (2009), terdapat beberapa pendekatan yang dapat digunakan dalam menganalisis data kualitatif yakni analisis tematik (thematic analysis), analisis naratif (narrative analysis), analisis percakapan atau ujaran (discourse analysis), dan analisis semiotik (semiotic analysis).

Terdapat juga pendekatan lain yang dapat digunakan dalam menganalisis data kualitatif, misalnya analisis isi (content analysis), dan teori grounded (grounded theory). Ritchie 
dan Lewis (2003) secara khusus mengklasifikasikan analisis data kualitatif ke dalam beberapa bentuk atau pendekatan analisis yakni analisis atau pendekatan etnografi (ethnographic account), sejarah hidup (life histories), narrative analysis, content analysis,conversation analysis, discourse analysis, induksi analitik atau analisis yang bersifat induktif (analytic induction), grounded theory, dan analisis evaluasi dan kebijakan (policy and evaluation analysis).

Istilah-istilah analisis data kualitatif tersebut tentunya memiliki ciri khas tersendiri baik dari segi proses atau tahap analisisnya maupun dari segi teknik analisisnya. Dalam hal ini, penulis berpendapat bahwa thematic analysis merupakan pendekatan yang paling banyak digunakan oleh peneliti kualitatif. Karenanya, peneliti akan memfokuskan pada bagaimana langkah-langkah melakukan thematic analysis. Pada umumnya, gambaran analisis data kualitatif terlihat pada thematic analysis. Dengan kata lain, ketika peneliti kualitatif telah mampu melaksanakan proses dan tahap thematic analysis, maka analisis data kualitatif lainnya akan mampu dilaksanakan oleh peneliti.

Thematic analysis atau biasa juga disebut dengan istilah analisis tematik interpretatif diartikan sebagai suatu metode dengan mengidentifikasi, menganalisis dan melaporkan tematema atau pola-pola yang terdapat dalam data. Menurut Liamputtong (2009), terdapat dua langkah utama yang harus dilakukan dalam thematic analysis. Pertama, peneliti membaca secara keseluruhan isi atau transkrip wawancara dan mencoba memberikan makna dari data transkrip tersebut. Dalam proses ini, peneliti memerhatikan secara seksama isi transkrip tersebut dan memberikan makna dari apa yang disampaikan oleh informan dalam konteks kolektifitas sebagai kelompok masyarakat. Dalam memahami isi transkrip tersebut, peneliti perlu memerhatikan pola-pola atau ide-ide yang berulang kali disampaikan oleh informan.

Pada tulisan ini, penulis menitikberatkan pada data wawancara yang telah diperoleh melalui wawancara (interview). Langkah awal pada proses ini adalah peneliti melakukan transkripsi wawancara. Proses ini umumnya mengambil waktu yang tidak sedikit mengingat data transkripsi akan digunakan untuk melakukan langkah pengkodean (coding). Liamputtong berpendapat bahwa data kualitatif secara umum mengimplementasikan langah coding dalam memahami makna atau polapola informasi yang ada pada data kualitatif. Coding adalah proses menelaah dan menguji data mentah yang ada dengan melakukan pemberian label (memberikan label) dalam bentuk kata-kata, frase atau kalimat.

Terdapat dua tahap dalam langkah coding ini yakni pengkodean awal (initial coding) atau pengkodean terbuka (open coding) dan pengkodean aksial (axial coding). Beberapa penulis menambahkan pentingnya pengkodean selektif (selective coding) dalam melakukan analisis data selain initial coding dan axial coding(lihatAuerbach 
dan Silverstein, 2003; Barbie, 2007; Blaikie, 2010; Hesse-Biber, 2010; Hesse-Biber dan Leavy, 2011). Initial coding diartikan sebagai pemberian makna atau label dalam bentuk katakata atau frase sesuai dengan data yang ada (misalnya pada data transkripsi). Axial coding diartikan sebagai langkah atau tahap kelanjutan dari open coding dengan cara menciptakan tema-tema atau kategori-kategori yang didasarkan pada kata-kata atau frase yang dihasilkan dari open coding.

Dalam melakukan coding, peneliti dapat menempuh berbagai cara atau pendekatan, misalnya dengan memanfaatkan feature new comment pada program microsoft office word, membuat kata-kata secara manual pada data transkripsi atau dengan menuliskan data transkripsi tersebut pada program microsoft office word dengan spasi 2 (dua), mencetak dan membuat label berupa kata-kata atau frase-frase singkat. Perlu diingat bahwa dalam melakukan coding, peneliti senantiasa dituntun oleh kerangka teoritis (teori) atau kerangka konseptual (conceptual framework) yang dijadikan landasan dalam penelitian yang sedang dilakukan. Banyaknya kode-kode, label ataupun kata-kata yang dihasilkan dari coding di atas menuntun peneliti untuk kreatif dan intuitif dalam membuat tema-tema (themes) dan kategori (categories) sesuai dengan jenis label yang dibuat pada initial coding.

Tema-tema yang telah dibuat melalui proses coding di atas perlu dikelompokkan dengan cara memilah tema-tema tersebut dengan memerhatikan prinsip hirarki, struktur atau cakupan tema-tema. Dalam membuat tema-tema dan kategori ataupun konsep, peneliti harus mampu memerhatikan keterkaitan atau koneksi antara satu tema dengan tema lainnya.

Langkah berikutnya adalah peneliti membuat atau menciptakan konsep-konsep atau gagasan-gagasan teoritis yang berkaitan dengan kode dan tema-tema tersebut. Strategi yang tepat dalam proses analisis data ini adalah kemampuan peneliti menghubungkan antara konsep-konsep yang telah dibuat dengan mengaitkan dengan teori-teori atau literaturliteratur yang telah ada. Dalam hal ini, peneliti harus senantiasa mencari dan melihat literatur yang telah ada yang mungkin relevan dengan isu penelitian yang sedang diteliti.

Mengingat coding adalah langkah penting dalam analisis data kualitatif, maka Liamputtong (2009 menyarankan beberapa tips praktis yang perlu diperhatikan oleh peneliti. Pertama, peneliti tidak perlu khawatir dengan banyaknya kode-kode atau label yang dibuat. Dalam praktiknya, peneliti akan menemukan bahwa kodekode yang dibuat mungkin tidak berkaitan atau sesuai dengan topik penelitian, namun di sisi lain, kodekode tersebut mungkin bermanfaat dalam konteks yang lain. Kedua, peneliti dapat membuat kode-kode atau label dengan cara yang kreatif dan variatif. Karena itu, peneliti perlu memerhatikan data-data penelitian secara seksama dan memahami secara mendalam data-data tersebut. Gambaran tahap analisis data kualitatif dapat dilihat pada bagan 1 . 


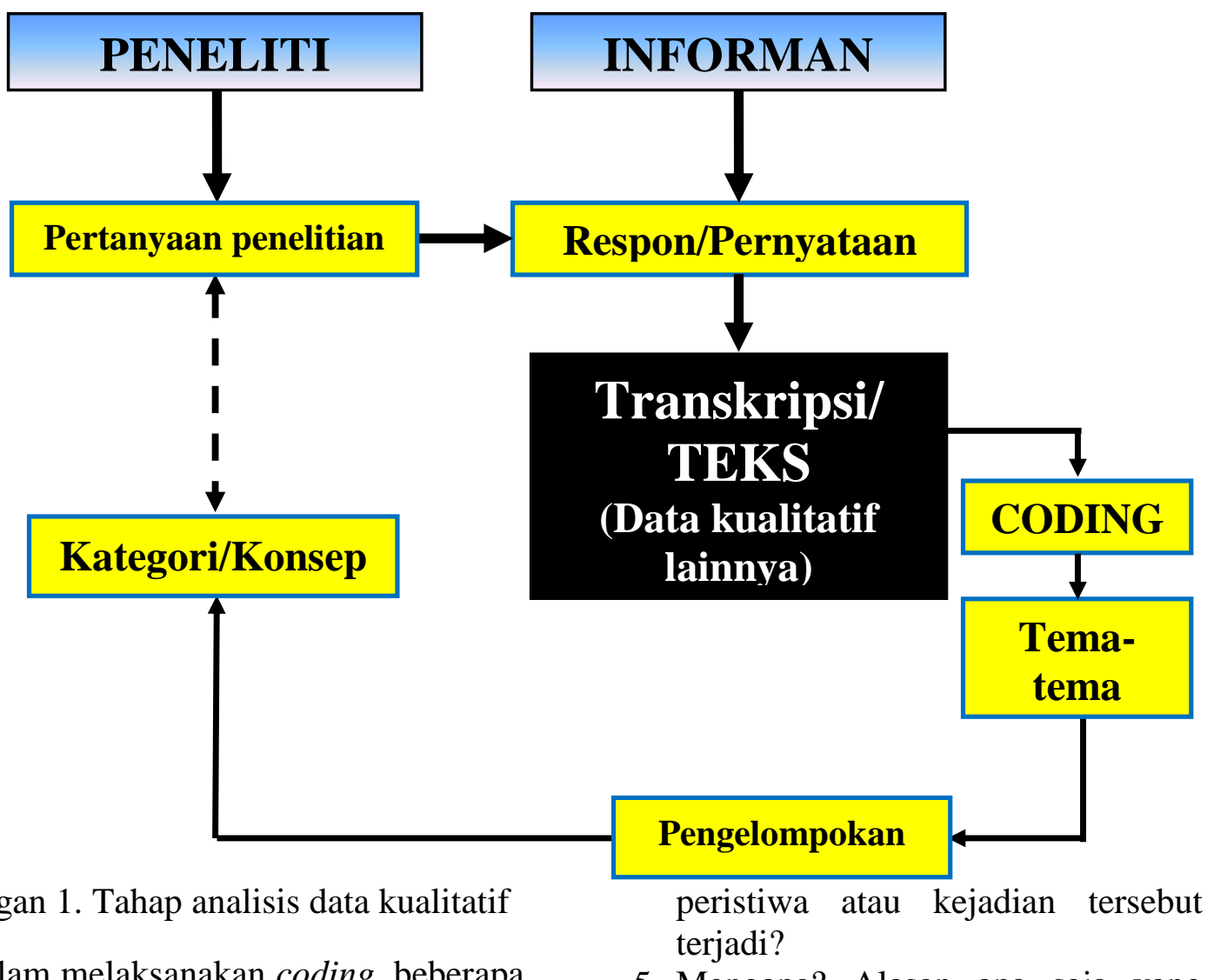

Dalam melaksanakan coding, beberapa pertanyaan berikut menjadi tuntunan (guidelines) bagi peneliti:

1. Apa? Apa yang menjadi isu utama dalam penelitian dan data ini?; apa yang disampaikan/disebutkan oleh informan?

2. Siapa? Siapa saja orang-orang yang terlibat; bagaimana peran orangorang ini?; bagaimana mereka berinteraksi?

3. Bagaimana? Aspek-aspek apa saja yang disebutkan atau diabaikan?

4. Kapan?Berapa lama? Dimana? Berkaitan dengan waktu dan lokasi; kapan sesuatu tersebut terjadi; berapa lama sesuatu tersebut terjadi atau berlangsung dan dimana

5. Mengapa? Alasan apa saja yang terdapat dalam data tersebut; atau alasan apa yang dapat dibangun berdasarkan data tersebut?

6. Untuk apa? Apa maksud dari data pernyataan informan; apa tujuannya?

7. Oleh siapa? Berkaitan dengan makna, strategi, dalam mencapai tujuan; apa taktik utama dari data tersebut; bagaimana sesuatu itu diselesaikan?

Ketujuh pertanyaan tersebut di atas dapat diimplementasikan dengan melihat apa yang sedang terjadi, apa yang dilakukan oleh kelompok atau individu, apa tujuan tindakan atau langkah yang sedang dilakukan dan 
bagaimana struktur dan kelembagaan mendukung mempertahankan atau berperan dalam tindakan atau taktik tersebut?

\section{Contoh Analisis Data Kualitatif Pada Penelitian Pariwisata}

Contoh pertama

Pada strategi pertama ini, peneliti melakukan wawancara ke beberapa orang (individu) dan menanyakan pertanyaan berikut: Upaya apa yang harus dilakukan untuk memaksimalkan manfaat pariwisata bagi masyarakat lokal? Selanjutnya, data-data berikut merupakan jawaban informan yang terlibat dalam wawancara tersebut:

- Perencaanan pariwisata harus lebih baik

- Penerapan peraturan dan regulasi yang baik

- Pengawasan peraturan

- Kebijakan pengembangan pariwisata di tingkat pusat harus ditindaklanjuti di tingkat daerah.

- Daerah harus siap dengan pengembangan pariwisata.

- Perlu koordinasi yang baik antara berbagai tingkatan pemerintah.

- Atraksi, aksesibilitas, amenitas dan anciliary harus baik.

- Memaksimalkan sekolah-sekolah pariwisata.

- Sumber daya manusia segera dikembangkan.

- Dominasi pemerintah dibatasi dalam pengelolaan aset. pariwisata

- Memberikan kesempatan masyarakat lokal mengelola homestay di sekitar daya tarik wisata
- Pemerintah daerah harus proaktif

- Melaksanakan event pariwisata yang menggambarkan karakteristik atau ciri khas destinasi

- Perlu analisis karakteristik daya tarik wisata

- Kebijakan pariwisata harus menjangkau masyarakat

Data-data di atas dilakukan pengkodean (coding) dengan membuat kategori-kategori (lihat tabel 1).

Jika peneliti menerapkan langkah coding ini, peneliti dapat menciptakan beberapa kategori (atau banyak kategori) sepanjang kategori tersebut memberikan makna dan dapat membantu peneliti dalam menginterpretasi data. Selanjutnya, tugas peneliti adalah melakukan langkah mengaitkan kategori-kategori tersebut untuk selanjutnya memberikan interpretasi data-data tersebut. 


\begin{tabular}{|c|c|}
\hline Kategori & Data \\
\hline Kebijakan & $\begin{array}{l}\text { - } \quad \text { Perencaanan pariwisata harus lebih baik } \\
\text { - } \quad \text { Daerah harus siap dengan pengembangan pariwisata } \\
\text { - } \quad \text { Semaksimalkan sekolah-sekolah pariwisata } \\
\text { - } \quad \text { Pemerintah daerah harus proaktif } \\
\text { - } \quad \text { Kebijakan pariwisata harus menjangkau masyarakat } \\
\text { - } \quad \text { Dominasi pemerintah dibatasi dalam pengelolaan aset pariwisata }\end{array}$ \\
\hline Pengelolaan & $\begin{array}{l}\text { - Perlu analisis karakteristik daya tarik wisata } \\
\text { - Melaksanakan event pariwisata yang menggambarkan karakteristik atau } \\
\text { ciri khas destinasi } \\
\text { - } \quad \text { Atraksi, aksesibilitas, amenitas dan anciliary harus baik }\end{array}$ \\
\hline $\begin{array}{l}\text { Implementasi } \\
\text { (peraturan) }\end{array}$ & $\begin{array}{l}\text { - } \quad \text { Pengawasan peraturan } \\
\text { - } \quad \text { Penerapan peraturan dan regulasi yang baik }\end{array}$ \\
\hline Koordinasi & $\begin{array}{l}\text { - } \quad \text { Kebijakan pengembangan pariwisata di tingkat pusat harus } \\
\text { ditindaklanjuti di tingkat daerah } \\
\text { - } \quad \text { Perlu koordinasi yang baik antara berbagai tingkatan pemerintah }\end{array}$ \\
\hline $\begin{array}{l}\text { Pemberdayaan } \\
\text { masyarakat }\end{array}$ & $\begin{array}{l}\text { - Memberikan kesempatan masyarakat lokal mengelola homestay di } \\
\text { sekitar daya tarik wisata }\end{array}$ \\
\hline
\end{tabular}

Tabel 1. Kategorisasi data penelitian

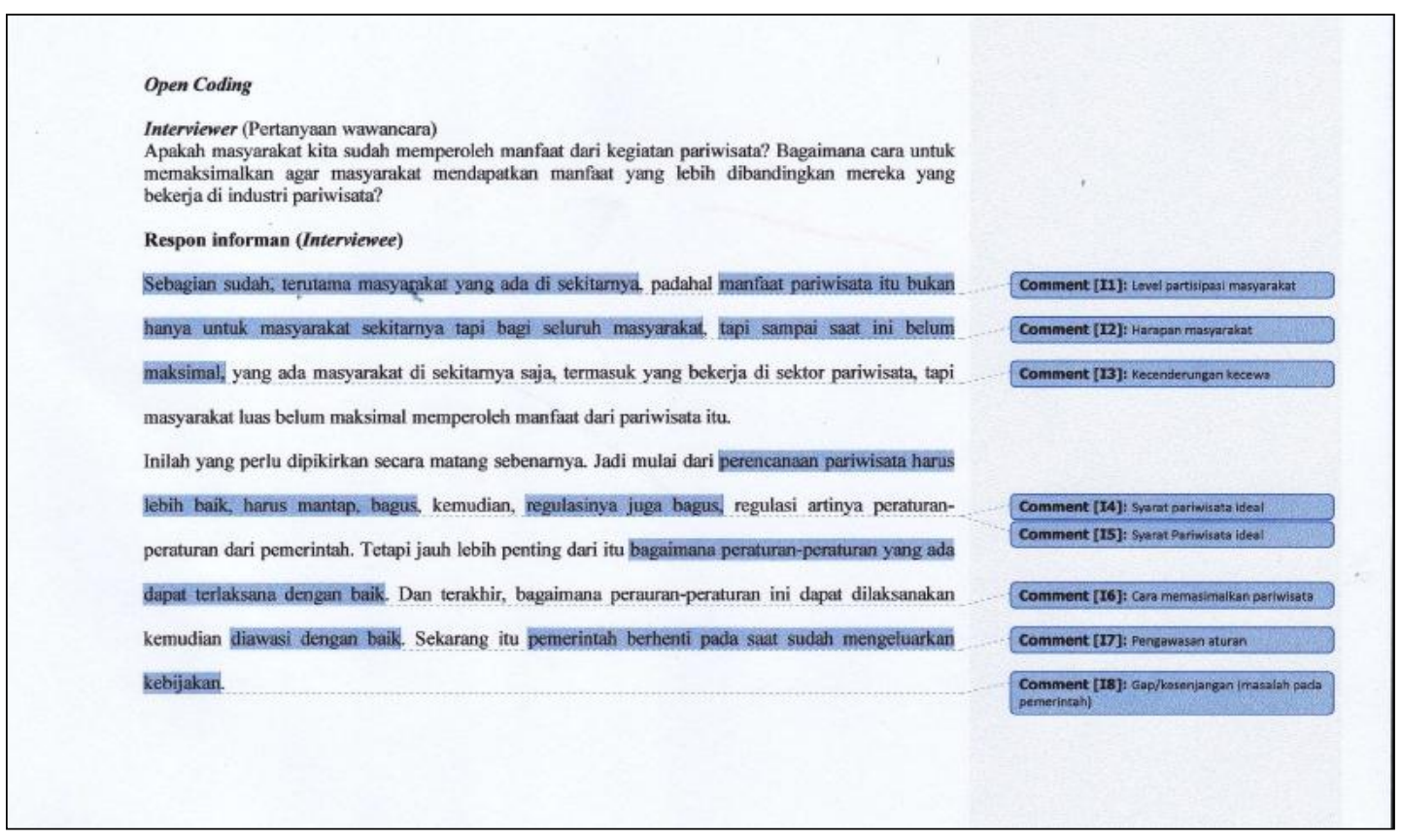

Gambar 1. Open coding

Jurnal Kepariwisataan, Volume 10, No. 01 Februari 2016, Halaman 59 - 74 
Contoh kedua

Open coding

Pada open coding, peneliti memberikan kode-kode seperti pada gambar 1. Selanjutnya, hasil open coding di atas dilakukan langkah axial coding, yakni membuat kategorisasi

atau pengelompokan data berdasarkan hasil open coding sebagaimana ditunjukkan pada tabel 2.

\begin{tabular}{|c|c|c|}
\hline Kode/label & Kategori/tema & Data \\
\hline $\begin{array}{l}\text { - Gap/kesenjangan } \\
\text { (masalah pada } \\
\text { pemerintah) } \\
\text { - Kecenderungan } \\
\text { kecewa } \\
\end{array}$ & $\begin{array}{l}\text { Permasalahan } \\
\text { pariwisata }\end{array}$ & $\begin{array}{l}\text { - Sekarang itu pemerintah berhenti pada saat } \\
\text { sudah mengeluarkan kebijakan. } \\
\text { - Tapi sampai saat ini belum maksimal, yang } \\
\text { ada masyarakat di sekitarnya saja, termasuk } \\
\text { yang bekerja di sektor pariwisata }\end{array}$ \\
\hline $\begin{array}{l}\text { - Level partisipasi } \\
\text { masyarakat } \\
\text { - Harapan } \\
\text { masyarakat }\end{array}$ & $\begin{array}{l}\text { Tingkat atau } \\
\text { level partisipasi } \\
\text { masyarakat } \\
\text { dalam kegiatan } \\
\text { pariwisata }\end{array}$ & $\begin{array}{l}\text { - Sebagian sudah, terutama masyarakat yang } \\
\text { ada di sekitarnya } \\
\text { - Manfaat pariwisata itu bukan hanya untuk } \\
\text { masyarakat sekitarnya tapi bagi seluruh } \\
\text { masyarakat }\end{array}$ \\
\hline $\begin{array}{l}\text { - Syarat pariwisata } \\
\text { ideal } \\
\text { - Cara } \\
\text { memaksimalkan } \\
\text { pariwisata } \\
\text { - Pengawasan } \\
\text { aturan }\end{array}$ & $\begin{array}{l}\text { Langkah atau } \\
\text { strategi } \\
\text { memaksimalkan } \\
\text { manfaat } \\
\text { pariwisata bagi } \\
\text { masyarakat }\end{array}$ & $\begin{array}{l}\text { Perencanaan pariwisata harus lebih baik, } \\
\text { harus mantap, bagus } \\
\text { - Regulasi juga harus bagus } \\
\text { - Bagaimana peraturan-peraturan yang ada } \\
\text { dapat terlaksana dengan baik } \\
\text { - Dan terakhir, bagaimana peraturan-peraturan } \\
\text { ini dapat dilaksanakan kemudian diawasi } \\
\text { dengan baik. }\end{array}$ \\
\hline
\end{tabular}

Tabel 2. Axial coding

Setelah melakukan langkah coding di atas, maka langkah berikutnya adalah mengaitkan kategori-kategori atau tema-tema di atas dengan tema-tema atau kategori yang dibuat dari hasil coding wawancara lainnya ataupun data kualitatif lainnya. Selanjutnya, peneliti diharapkan melakukan interpretasi data berdasarkan teori atau kerangka konseptual yang dijadikan pegangan dalam melakukan penelitian.
Interpretasi ini menuntut kemampuan peneliti dalam menghubungkan antara data yang satu dengan data lainnya serta kemampuan dalam memahami makna secara menyeluruh (komprehensif). Peneliti kualitatif dapat menggaris bawahi pernyataan ataupun data dari informan yang akan dikutip dalam pelaporan hasil penelitian ataupun penulisan karya tulis. 


\section{KESIMPULAN}

Salah satu tujuan utama dari penelitian kualitatif adalah untuk menjawab masalah-masalah yang terjadi dalam konteks sosial di masyarakat. Selanjutnya, hasil penelitian tersebut diharapkan dapat memberikan kontribusi baik yang bersifat solusi ataupun pendekatan terhadap masalah penelitian maupun pengembangan ilmu pengetahuan dalam bidang kajian keilmuan yang diteliti. Tujuan ini hanya dapat tercapai jika peneliti menerapkan langkahlangkah ilmiah sesuai dengan prinsip metodologi penelitian yang diterapkan.

Analisis data kualitatif adalah salah satu prinsip utama agar suatu penelitian mampu memberikan kontribusi terhadap pengembangan pengetahuan termasuk di bidang pariwisata. Jenis data yang diperoleh dalam penelitian kualitatif (dalam bentuk kata atau kalimat) menuntut peneliti untuk mampu mereduksi, mengorganisir dan menginterpretasi data tersebut.

Terdapat beberapa bentuk atau istilah yang digunakan dalam menganalisis data kualitatif. Fokus utama tulisan ini adalah implementasi thematic analysis melalui langkah coding. Umumnya, coding menjadi bagian tak terpisahkan dari analisis data kualitatif. Karenanya, peneliti kualitatif perlu menerapkan langkah ini mengingat reduksi data interpretasinya hanya dapat dilakukan jika peneliti memahami varian data yang ada.

Mengingat studi pariwisata juga tidak terlepas dari penerapan metode wawancara, observasi, diskusi terfokus dan analisis dokumen, maka peneliti pariwisata dapat menerapkan thematic analysis melalui langkah coding. Penelitian kualitatif di bidang pariwisata menghendaki implementasi prosedur yang ilmiah. Pemahaman dan penerapan langkah analisis ini dapat menghasilkan penelitian yang kuat (robust) yang selanjutnya kriteria keilmiahan penelitian kualitatif dapat terpenuhi.

\section{DAFTAR PUSTAKA}

Alasuutari, Pertti. 2010. The rise and relevance of qualitative research. International Journal of Social Research Methodology, Vol. 13, No. 2, Hal. 139-155.

Auerbach, Carl. F., dan Silverstein, Louise, B. 2003. Qualitative data: an introduction to coding and analysis (coding the basic ideas). New York: New York University Press.

Altinay, Levent., dan Paraskevas, Alexandros. 2008. Planning Research in Hospitality and Tourism: Butterworth-Heinemann.

Babbie, E. 2007. The practice of social research. Belmont: Thomson.

Baez, Benjamin. 2002. Confidentiality in qualitative research: reflections on secrets, power and agency. Qualitative Research, Vol. 2, No. 1, Hal. 35-58.

Belsky, Jill. 2004. Contributions of qualitative research to understanding the politics of community ecotourim. Dalam Phillimore, Jenny., dan Goodson, Lisa. Editor.Qualitative research 
in tourism: ontologies, epistemologies and methodologies. New York: Routledge. Hal. 273-291.

Blaikie, Norman. 2010. Designing social research (2nd ed.). Cambridge: Polity Press.

Brown, Alison, P. 2010. Qualitative method and compromise in applied social research. Qualitative Research, Vol. 10, No. 2, Hal. 229-248.

Bryman, Alan. 1998. Quantity and quality in social research, London: Unwin Hyman.

Bryman, Alan., Becker, Saul., dan Sempik, Joe. 2008. Quality criteria for quantitative, qualitative and mixed methods research: a view from social policy. International Journal of Social Research Methodology, Vol. 11, No. 4, Hal. 261-276.

Decrop, Alain. 2004. Trustworthiness in qualitative tourism research. Dalam Phillimore, Jenny., dan Goodson. Lisa. Editor. Qualitative research in tourism: ontologies, epistemologies and methodologies New York: Routledge. Hal. 156169.

Decrop, Alain. 1999. Triangulation in qualitative tourism research. Tourism Management Vol. 20, Hal. 157-161.

Denzin, Norman.K., dan Lincoln, Yvonna.S. Editor. 2000. Handbook of qualitative research, 2nd edition, Thousand Oaks: Sage.

Dey, Ian. 1993.Qualitative data analysis: a user-friendly guide for social scientists. London: Routledge.

Fielding, Jane., dan Fielding, Nigel. 2008. Synergy and synthetis: integrating qualitative and quantitative data. Dalam Alasuutari, Pertti., Bickman, Leonard., dan Brannen, Julia. Editor. The SAGE handbook of social research methods. London: SAGE. Hal. 555-571.

Flick, Uwe. 2007. Designing qualitative research. London: SAGE.

Flick, Uwe., Kardorff, Ernst von. dan Steinke, Ines. 2004. What is qualitative research? an introduction to the field. Dalam Flick, Uwe., Kardorff, Ernst von., dan Steinke, Ines. Editor. A companion to qualitative research. London: SAGE. Hal. 312.

Goodson, Lisa., dan Phillimore, Jenny. 2004. The inquiry paradigm in qualitative tourism research, in Qualitative research in tourism: ontologies, epistemologies and methodologies. Dalam Phillimore, Jenny., dan Goodson, Lisa. Editor. Routledge: New York. Hal. 3-29.

Hesse-Biber, Sharlene. 2010. Qualitative approaches to mixed methods practice. Qualitative Inquiry, Vol. 16, No. 6, Hal. 455468.

Hesse-Biber, Sharlene Nagy., dan Leavy, Patricia. 2011. The practice of qualitative research (2nd ed.). California: SAGE.

Junaid, Ilham. 2015. Etika penelitian pariwisata, perspektif teori dan 
praktik. Jurnal Ilmiah Pariwisata, Vol. 20 No. 1, Hal. 14-30.

Liamputtong, 2009. Qualitative data analysis: conceptual and practial considerations. Health Promotion Journal of Australia, Vol. 20, No. 2, Hal. 133.

Long, Jonathan. 2007. Researching leisure, sport and tourism: The essential guide. London: SAGE.

Moore, Nick. 2006.How to do research: A practical guide to designing and managing research projects (analysing qualitative data).London: Facet publishing.

Maykut, Pamela., dan Morehouse, Richard. 1994. Beginning qualitative research: A philosphic and practical guide. London: The Palmer Press.

Phillimore, Jenny., danGoodson, Lisa. 2004. Progress in qualitative research in tourism: Epistemology, ontology and methodology. Dalam Phillimore, Jenny., dan Goodson, Lisa. Editor.Qualitative research in tourism: Ontologies, epistemologies and methodologies. New York: Routledge. Hal. 3-29.

Ritchie, Jane. 2003.The applications of qualitative methods to social research. Dalam Ritchie, Jane., dan Lewis, Jane. Editor. Qualitative research practice: $A$ guide for social science students and researchers. 2003, SAGE: London. Hal. 24-34.

Ritchie, Jane., Spencer, Liz., dan O'Connor, William. 2003. Carrying out qualitative analysis. Dalam Ritchie, Jane., dan Lewis, Jane. Editor. Qualitative research practice: A guide for social science students and researchers. London: SAGE. Hal. 219-262.

Seale, Clive. 2004. Validity, reliability and the quality of research. Dalam Seale, Clive. Editor. Researching society and culture (2nd ed). London: SAGE. Hal. 71-84.

Snape, Dawn., dan Spencer, Liz. 2003. The foundations of qualitative research. Dalam Ritchie, Jane., dan Lewis, Jane. Editor. Qualitative researh practice: A guide for social science students and researchers. London: SAGE. Hal. 1-23.

Steinke, Ines. 2004. What is qualitative research? an introduction to the field. Dalam Flick, Uwe., Kardorff, Ernst von., dan Steinke, Ines. Editor. A companion to qualitative research. London: SAGE. Hal. 184-190. 